\title{
A Comparison of Several Noninverting Ion-Exchange Systems used in the Purification of Puerto Rican Sugarcane Juices ${ }^{1}$
}

\author{
B. A. Smith, F. Sánchez-Nieva, M. A. González, \\ and M. Matos-Maldonado ${ }^{2}$
}

\section{INTRODUCTION}

Evaluation of a noninverting reverse-cycle ion-exchange processes for purifying clarified sugarcane juices was undertaken in Puerto Rico in 1955 to determine whether the effectiveness of this procedure reported earlier with juices from relatively immature Louisiana canes $(1,2,3)^{3}$ could be duplicated with the juices from mature tropical canes. Data obtained showed that insertion of this ion-exchange purification step between rawjuice clarification and evaporation of clarified juice to syrup improved the quality of the Puerto Rican juices so that the quantity of available sugar was significantly increased, and the crystallized sugars approximated refined sugars in ash and color (4). These sugars were suitable for use, without refining, by the confectionery or other industries where the turbidity of their syrups was not objectionable.

The use of salt-cycle ion-exchangers to provide inexpensive eliminations of limited quantities of color and other impurities in the refining of raw cane sugars has been reported $(5,6)$. Combinations of exchangers of this type with those of the reverse-cycle system offered possibilities of providing direct-consumption sugars superior in quality to those available from the reverse-cycle process alone. Experiments were undertaken to evaluate several such mixed cycles and compare the quality of juices obtained with that available from the reverse-cycle procedure.

' Contribution from the Agricultural Experiment Station, University of Puerto Rico, Río Piedras, P.R., and the Southern Utilization Research and Development Division, ARS, USDA.

3 Chemist, Sugarcane Investigations, Food Crops Laboratory, Southern Utilization Research \& Development Division, New Orleans, La., USDA; and Technical Director, Assistant Chemical Engineer, and Research Assistant in Chemistry, respectively, Food Technology Laboratory, Agricultural Experiment Station, Rio Piedras, P.R. The authors wish to acknowledge the assistance of the following for their contribution to this work: Rohm \& Haas Co., Phila., Pa., for kindly supplying the ion-exchange resins IRA-410, IRA-401S, IRC-50, and IR-120 used in these experiments; Mr. Gonzalo Serbia, Research Chemist for Central Aguirre, Aguirre, P.R., for valuable advice on the use and regeneration of salt-cycle exchanger resins; the various members of the Agricultural Experiment Station stafi, and especially the staff of the Food Technology Laboratory whose cooperation made this work possible.

${ }^{8}$ Italic numbers in parentheses refer to Literature Cited, p. 254. 


\section{EQUIPMENT AND MATERIALS}

Semi-pilot plant facilities of the Food Technology Laboratory employed for these tests consisted of five 6-inch outside-diameter stainless steel and clear plastic columns to contain the ion-exchange resins, and the appropriate corrosion-resistant pumps, tanks, valves, and connecting lines required for processing from 10 to 15 gallons of juice per hour. The columns were connected in a manner permitting juice to be pumped through any desired number or sequence of exchanger beds. Juices or water entered each column through a feed distributor located just above the surface of the exchanger resin, and flow through the series of beds was maintained by individually controlled air-pressure domes above each resin bed. A conductivity recorder connected to a conductance cell in the juice flow-line above the productreceiving tank permitted determination of the quality of the product juice.

The reverse-cycle arrangement of exchangers employed for these investigations consisted of approximately 0.7 cubic foot of the quaternary-type anion resin IRA-410 in the first position, followed by approximately 0.3 cubic foot of a carboxylic acid-type cation-exchanger in second, 0.5 cubic foot of a scavenging anion mixture of the quaternary resin IRA-401S, and a weakbase amine type resin A-2 in the third position. ${ }^{4}$ Two additional beds to contain 0.5 cubic foot of resin each were provided for salt or mixed-cycle experiments. One of these columns contained the sulfonic acid-type cation exchanger IR-120, and the other the anion resin IRA-401S. The order of arrangement of the ion-exchange resin columns in the various cycles investigated is presented in table 1.

\section{PROCEDURES}

Lots of sugarcane grown by the Agricultural Experiment Station for agronomic investigations were crushed by a double pass through a sampling mill at Río Piedras to provide juices for these tests. The mill-train consisted of two "Cuba-type" three-roll units, each roll 12 by 16 inches with peripheral V-shaped grooving. Two thousand pounds of pressure per square inch was applied to the roll units which were operated at a capacity of 1.5 tons of cane per hour. No water was applied to the cane during crushing, so that the raw juices obtained approximated in Brix and purities the crusher juices produced by commercial milling of sugarcane. These raw juices were promptly limed to a $\mathrm{pH}$ of 8.0 to 8.1, heated, and settled in an open batchtype defecator at the Food Technology Laboratory, and the clear super-

4 Ion-exchange resins IRA-410, IRA-401S, IRC-50, and IR-120 were provided by Rohm and Haas Co., Philadelphia, $\mathrm{Pa}$., and the A-2 resin was obtained from Chemical Process Co., Redwood City, Calif. The mention of these products does not imply endorsement by the Puerto Rico Agricultural Experiment Station or the U.S. Department of Agriculture as superior to similar products not mentioned. 
TABLE 1.-Arrangement of ion-exchange resin columns in various cycles

\begin{tabular}{|c|c|c|c|c|c|}
\hline Cycle & Column No. ${ }^{11}$ & Column No. 2 & Column No. ${ }^{32}$ & Column No. 4 & Column No. 5 \\
\hline Reverse & $\begin{array}{l}\text { Anion: } \\
\text { IRA-410(OH) }\end{array}$ & $\begin{array}{l}\text { Cation: } \\
\text { IRC-50(H) }\end{array}$ & $\begin{array}{l}\text { Mixed-anion; A2, } \\
\text { IRA-401S(OH) }\end{array}$ & & \\
\hline Mixed No. 1 & $\begin{array}{l}\text { Anion: } \\
\text { IRA-410(OH) }\end{array}$ & $\begin{array}{l}\text { Cation: } \\
\text { IRC-50(H) }\end{array}$ & $\begin{array}{l}\text { Anion: } \\
\text { IRA-401S(Cl) }\end{array}$ & $\begin{array}{l}\text { Mixed-anion; } A 2, \\
\text { IRA-401S(OH) }\end{array}$ & \\
\hline Mixed No. 2 & $\begin{array}{l}\text { Anion: } \\
\text { IRA-410(OH) }\end{array}$ & $\begin{array}{l}\text { Cation: } \\
\text { IRC-50(H) }\end{array}$ & $\begin{array}{l}\text { Mixed-anion; A2, } \\
\text { IRA-401S(OH) }\end{array}$ & $\begin{array}{l}\text { Cation: } \\
\text { IR-120(Na) }\end{array}$ & $\begin{array}{l}\text { Anion: } \\
\text { IRA-401S(Cl) }\end{array}$ \\
\hline Mixed No. 3 & $\begin{array}{l}\text { Cation: } \\
\text { IR-120(Na) }\end{array}$ & $\begin{array}{l}\text { Anion: } \\
\text { IRA-401S(Cl) }\end{array}$ & $\begin{array}{l}\text { Anion: } \\
\quad \text { IRA-410(OH) }\end{array}$ & $\begin{array}{l}\text { Cation: } \\
\text { IRC-50(H) }\end{array}$ & \\
\hline Mixed No. 4 & $\begin{array}{l}\text { Cation: } \\
\text { IR-120(Na) }\end{array}$ & $\begin{array}{l}\text { Anion: } \\
\text { IRA-401S(Cl) }\end{array}$ & $\begin{array}{l}\text { Anion: } \\
\text { IRA-410(OH) }\end{array}$ & $\begin{array}{l}\text { Cation: } \\
\text { IRC-50(H) }\end{array}$ & $\begin{array}{l}\text { Mixed-anion; A2, } \\
\text { IRA-401S(OH) }\end{array}$ \\
\hline Salt & $\begin{array}{l}\text { Cation: } \\
\text { IR-120(Na) }\end{array}$ & $\begin{array}{l}\text { Anion: } \\
\quad \text { IRA-401S(Cl) }\end{array}$ & & & \\
\hline
\end{tabular}

1 The use of $(\mathrm{OH})$ or $(\mathrm{H})$ following identification of the exchanger resin indicates that the resins were in the hydroxyl or hydrogen form, respectively. Similarly, use of $(\mathrm{Na})$ or $(\mathrm{Cl})$ indicates that the resin had been exhausted to the sodium ion or chloride ion, respectively, before use.

2 Mixed-anion bed was 60 percent by volume A-2 and 40 percent IRA-401S resin. 
natant clarified juices so obtained were refrigerated for use on the following day.

Similar procedures were followed in ion-exchange treatment of the juices in all tests insofar as was practically possible. Chilled feed juices were either weighed or measured by volume, sampled, warmed to approximately $50^{\circ} \mathrm{C}$., and passed through the desired series of exchanger beds at a flow-rate of 10 to 12 gallons per hour. The conductance measured on the juice flow from the last exchanger bed determined the quantity of juice processed per test, and when rising conductivity reached a predetermined cut-off value, pumping of feed juice to the first exchanger was stopped, and water was passed through the series of beds to rinse out the juice until a reading of 0-percent refractometric solids was obtained on the effluent. The conductance selected as the cut-off point for juice feed in all reverse-, and mixed-cycle experiments was 250 micromhos, while a decrease in conductance coinciding with increasing juice $\mathrm{pH}$ provided the cut-off point for salt-cycle tests.

All product juices were collected on completion of the test, mixed, and sampled before discard. The exchanger beds were then backwashed individually by an upward flow of water to remove precipitated or trapped solids, and to reclassify the resins. In all experiments employing the IRA-410 resin as the first exchanger of the series, this anion-bed always contained a voluminous floc composed of waxes, bagacillo, protein, silica, and the insoluble hydroxides formed when the resin liberated the bases of the juice minerals. The removal of these sediments required agitation of the suspended exchanger resin by air from jets located at the surface of the bedsupport media until the resin particles were freed of these materials. Subsequent backwashing then rinsed such sediments from the exchanger-bed effectively.

Chemical regeneration of the exchanger-beds followed the backwashing step. The IRC-50 cation resin was treated with 701 . of $0.2 \mathrm{~N} \mathrm{H}_{2} \mathrm{SO}_{4}$ and the mixed-anion scavenger with 31 . of $2 \mathrm{~N} \mathrm{NaOH}$. Regeneration of the IRA-410 anion-bed followed a procedure reported by Fort and Smith (3), where the usable free $\mathrm{NaOH}$ content of a fraction of the waste regenerant saved from a previous treatment of this exchanger was recycled prior to adding fresh alkali. Sufficient fresh alkali was used to provide a total of $38 \mathrm{gm}$.-equiv. weights of $\mathrm{NaOH}$ per test. This recycling of alkali saved approximately one-half of the alkali otherwise required to regenerate the resin adequately. Following chemical regeneration of the resin-beds, water was used to rinse either free acid or alkali from the individual beds to a level of approximately $0.001 \mathrm{~N}$ on the runnings.

The salt-cycle anion and cation exchangers employed in some of these tests required regeneration with $\mathrm{NaCl}$, and the anion-bed an additional treatment with sodium hydrosulfite to reduce organic fouling of the resin. 
Two hundred pounds of a clear, 10-percent brine solution at 65 to $70^{\circ} \mathrm{C}$. were used to regenerate the two resins in series, anion through cation to waste. Pumping was stopped when about one-half of the brine had passed through the anion-bed, and the brine was rinsed from the anion resin with warm, then cool water, and 6 gallons of a 0.25-percent solution of sodium hydrosulfite were pumped into the bed to stand for approximately 1 hour. The hydrosulfite solution was then rinsed from the resin to waste with warm, then hot water before use of the remainder of the brine to complete regeneration of the anion and cation resins. Excess brine was rinsed from these two resin-beds with warm, then cool water.

\section{ANALYTICAL METHODS}

The analytical methods employed in these investigations followed procedures established for the cane-sugar industry, including dry solids by lowtemperature vacuum-oven drying on sand, carbonate ash after incineration at $550^{\circ} \mathrm{C}$, reducing substances by the Lane-Eynon method, true-purity based on chemical determination of sucrose, protein by Kjeldahl nitrogen $X$ 6.25 , and turbidity and color after the method of Balch (7).

\section{RESULTS AND DISCUSSION}

Eighteen of the thirty-two experiments in this series were made with the reverse-cycle arrangement of resins in order to establish procedures for economy in regeneration of the IRA-410 anion resins. The recycling of regenerant alkali produced no detectable effect on the quality of the product juices, so that data from these tests were used for comparison with the mixed and salt-cycle test data. Information on various phases of regeneration will be published later.

The feed juices used for these tests differ from those normally obtained by centrals in that they were derived from canes grown for various agronomic studies, and were produced by crushing the canes in an experimental mill. The former condition provided juices which varied considerably in ash, color, protein, and reducing substances, while the latter provided juices with the high average true purity of 89 , which more closely approximated the purity of crusher juice than that of normal juice. Large variations in juice composition limited interpretation of the analytical data, since eliminations of juice impurities were affected by the kind as well as by the quantity of juice impurity present.

Average data obtained from one reverse, one salt, and four mixed-type cycles are presented in table 2 . With the exception of the reverse cycle, too few tests were made with any arrangement of exchangers to establish its performance beyond question. The criteria used to determine whether to continue investigation of a mixed cycle were the eliminations of ash, color, 
protein, and turbidity effected by the particular arrangement of ion-exchange resins as compared with similar data from reverse cycle processing. Several of the mixed cycles provided greater increases in true purity than the reverse cycle, but color removals were not significantly improved, and turbidity and protein eliminations were poorer than with the reverse-cycle system. Installation and regenerant chemical requirements of the threecolumn reverse-cycle system were less than those of the four- and five-column systems tested. These data show that little justification existed for further exploration of any of the mixed cycles.

Certain comparisons of the mixed cycles tested are possible under the limitations of insufficient testing with each resin arrangement and large variations in feed juice composition. Two of the mixed cycles, Nos. 1 and 2,

TABLE 2.-Comparison of various ion-exchange cycles

\begin{tabular}{|c|c|c|c|c|c|c|}
\hline \multirow{2}{*}{ Type of cycle } & \multirow{2}{*}{$\begin{array}{c}\text { Re- } \\
\text { verse }\end{array}$} & \multicolumn{5}{|c|}{ Mixed } \\
\hline & & No. 1 & No. 2 & No. 3 & No. 4 & Salt \\
\hline Tests averaged............. number & 18 & 3 & 2 & 2 & 2 & 3 \\
\hline .......... percent solids & 1.66 & 1.80 & 1.31 & 1.50 & 1.63 & 1.94 \\
\hline Protein in feed............ do. & .63 & .26 & .26 & .28 & .27 & .88 \\
\hline True purity rise. . & 3.7 & 5.0 & 4.3 & 3.1 & 4.9 & 1.4 \\
\hline Ash removed $\ldots \ldots \ldots \ldots \ldots$ percent & 93.1 & 90.6 & 92.4 & 90.1 & 92.9 & $15.0^{1}$ \\
\hline Protein removed........... do. & 74.4 & 71.0 & 41.7 & 40.3 & 60.9 & 14.5 \\
\hline Reducing substances removed... do. & 6.7 & 5.7 & 6.1 & 3.3 & 5.1 & - \\
\hline Color removed ............. do. & 93.0 & 94.0 & 91.0 & 85.0 & 96.0 & 45.0 \\
\hline Turbidity removed......... do. & 81.0 & 75.0 & 75.0 & 43.0 & 56.0 & $15.0^{1}$ \\
\hline
\end{tabular}

${ }^{1}$ Values estimated.

and the reverse cycle, were arranged with the hydroxyl form of a highly basic anion resin in first position, followed by a carboxylic-type cation-exchanger in second position. While the purity rises and constituent removals other than reducing substances were not significantly affected by this sequence of exchangers, it is obvious that elimination of turbidity materials was greatly improved by this arrangement. This turbidity elimination probably resulted from a trapping of juice suspended matter by the insoluble hydroxides of juice cations which formed following liberation of the free bases in this first anion-exchanger.

All of the cycles listed in table 1, except the reverse cycle, included the chloride form of the anion-exchanger IRA-401S. It is interesting to note that inclusion of this exchanger did not consistently provide significant improvement in color removal over that obtained with the simpler reverse cycle. Apparently the color bodies of clarified cane juices differ from those 
of melted sugarcane raws, or the quantity present in the juices exceeded the capacity of this exchanger. Also, the lower color-removing efficiency of the mixed No. 3 cycle, the only demineralizing cycle where the mixed anion-bed was absent, suggests that this resin mixture has great capacity for the color bodies of cane juices, and is therefore a very valuable part of the effectiveness of the reverse cycle for color removal. Data from the cycles where the sodium form of the cation exchanger IR-120 were used reveal no advantages for use of this exchanger. Purity rises and eliminations of impurities were not improved.

\section{SUMMARY}

Tests were made with five different demineralizing arrangements of ionexchange resins in the purification of clarified sugarcane juices, but none provided juices superior in quality to those obtained from the reverse-cycle system. Feed juices of variable composition and high purities, and limited testing with the various mixed cycles preclude precise determination of the performance of these arrangements of exchangers, but ash, protein, color, and turbidity removals were insufficient to justify extensive testing. Purity increases obtained with most mixed cycles were found to equal or exceed that from the reverse cycle, indicating that more crystalline sugar would be available from the product juices, but the advantage of such additional sugar would be cancelled by the greater expense of installation and operation of four or five exchanger-beds, as compared with that for the three-bed reverse-cycle system.

\section{RESUMEN}

Se ensayaron cinco diferentes sistemas de permutación iónica para la purificación del jugo de caña clarificado. De los sistemas ensayados que incluían diferentes combinaciones de resinas de permutación de iones, ninguno resultó superior a la combinación de ciclo invertido, donde el jugo se trató primeramente con resinas aniónicas y luego con la catiónica.

Debido a variaciones en la composición de los jugos usados en estas pruebas y al número limitado de pruebas que se pudieron llevar a cabo, no fue posible establecer en forma precisa y final la efectividad de los varios sistemas ensayados, pero la remoción de la ceniza, proteína, color y turbiedad de los jugos por los varios ciclos ensayados, a excepción del ciclo invertido, no parecían justificar el conducir pruebas adicionales. El aumento en la pureza de los jugos tratados con casi todas las combinaciones de resinas usadas fueron de igual magnitud al que se obtuvo al tratar los jugos clarifcados por el ciclo invertido. Aunque en algunos casos el aumento en pureza fue superior al obtenido del ciclo invertido, la recuperación adicional de azúcar que podría obtenerse de estos jugos no justifica el uso de estos siste- 
mas, ya que el costo de instalación y operación de sistemas de columnas múltiples sería más alto que la operación de las tres columnas usadas en el sistema de ciclo invertido.

\section{LITERATURE CITED}

1. Fort, C. A., and Smith, B. A., Reverse cycle demineralization of sugarcane juices with ion-exchange resins, Sugar $J .15$ (9) pp. 16, 18, 22-5, 1953.

2. Fort, C. A., Smith, B. A., and Martin, L. F., Comparison of the Effectiveness of Selected Ion-exchange Resins for the Purification of Clarified Sugarcane Juices, Proc. 3d Tech. Session on Bone Char, pp. 179-98, 1954.

3. Fort, C. A., and Smith, B. A., Ion-exchange: Quality of sugar produced by reverse cycle purification of juices, Sugar 60 (4) pp. 43-5, 1955.

4. Smith, B. A., Sánchez-Nieva, F., Colon, L. F., and Coll, E. E., Experiments on purification of Puerto Rican sugarcane juices, Sugar $J .19$ (12) pp. 20-1, 58-61, 1957.

5. Conklin, C. D., and Cangelosi, A., Use of Highly Basic Resins in Sugar Refining, Proc. 6th Tech. Session on Bone Char, pp. 31-52, 1959.

6. Kunin, R., Ion Exchange Resins, 2nd. ed., p. 183, John Wiley \& Sons, Inc. New York, N.Y., 1958.

7. Balch, R. T., Measurement of turbidity with a spectrophotometer with special reference to sugarhouse products, Ind. Eng. Chem., Anal. Ed., 3 124, 1931. 